\title{
DEVELOPMENT OF BIOFUELS PRODUCTION FROM AGRICULTURAL RAW MATERIALS
}

Ludwik WICKI, Department of Economic and Organization of Enterprises, Faculty of Economic Sciences, Warsaw University of Life Sciences-SGGW, Nowoursynowska 159 C, 02-776 Warsaw, Poland ludwik wicki@sggw.pl

\begin{abstract}
The aim of the article is to assess the dynamics of the development of biofuels production from agricultural raw materials and the share of biofuels in the consumption of the most important agricultural raw materials with particular regard to the situation in Poland. Data used in the study are derived from OECD statistics as well as CSO statistics. The analysis covered the period from 2005 to 2016 . The biofuel production on a global scale is increasingly competing with food production. Between 2002 and 2004, about 2\% of harvested cereals were allocated to biofuels, and in 2016 it was almost $8 \%$. For oil plants, this level reached $15 \%$. Following a dynamic growth in biofuel production between 2005 and 2010, the growth slowed down considerably - to the level of $7 \%$ annually for biodiesel and $4.6 \%$ annually for bioethanol production. For the years $2017-2025$, a growth rate of about $1 \%$ per year is anticipated. The slowdown in production growth is due to the reduction of political support for the development of the production of biofuels from first generation raw materials. Their production leads to competition for land resources with food production, but it has also been found to be characterized by relatively low environmental performance, including a low impact on the reduction of $\mathrm{CO}_{2}$ emissions. It is necessary to develop the production of second generation biofuels which now account for only about $7 \%$ of the production of liquid biofuels. Biofuels in Poland are produced from cereals and rapeseed oil. The production of biofuels in Poland increased from 180 million litres in 2005 to 1.2 billion litres in 2015. 1.3\% of arable land was used for bioethanol production and 3.5\% for biodiesel production. Total production of raw materials for biofuels was conducted on 5\% of arable land in Poland. $2 \%$ of cereals and $60 \%$ of the rape crop were consumed for the production of biofuels. Under Polish agriculture conditions, biofuels production does not compete with food production yet.
\end{abstract}

Keywords: bioenergy, biofuels, biofuel prices, biomass, energy crops, renewable energy

\section{INTRODUCTION}

The confusion caused by the shortage of certain raw materials and the doubling of prices of some raw food observed in 2008 was a signal that the volume of food produced in the world may not be sufficient for the growing population of the world. Among others, this was due to the observed slowdown in the growth of productivity in agriculture, but also due to the growing demand in agricultural raw materials. Scenarios for the future predict that there will be an increase in competition for land for the production of raw materials for bioenergy production. The intensity of this competition will depend on the prices of fossil fuels, but also on the progress achieved in the scope of yielding of plants allocated to bioenergy production and progress in biomass conversion technologies (Golebiewski and Pajak, 2016, Sands et al., 2017). The possibilities of energy production from biomass are overestimated in many cases. Searle and Malins (2014) found that primary energy production from biomass can reach 40-110 EJ per year in 2050, and taking into account the biomass from waste and forestry it can be 60-120 EJ per year. Similar results were presented by the International Energy Agency $(2011,2012)$. This means that production assumed in some scenarios of up to 600 EJ per year (Hoogwijk, 2005, 2009) cannot be achieved sustainably, including without greater environmental pressure and greater competition with food production. Some of the studies on bioenergy production have been based on political documents, and have assumed a linear growth in production over the long term, which seems to be the cause of over-estimation.

The increase in agricultural production in the world in the years 1960-1990 was mainly due to the increase of use production inputs per hectare. After 1990, the importance of increasing production intensity in achieving agricultural production growth decreased to $15 \%$, and the importance of technical progress (TFP measured) increased to around $67 \%$ (Fuglie et al. 2012, Fuglie and Rada 2017); The total annual growth of agricultural production decreased from almost $3 \%$ to $2-2 . \%$. This means that estimations of biomass production in the future need to include less surplus production. At the same time, about $18 \%$ of the world's population is not provided with food security, i.e. they have no permanent access to sufficient quantity of food (Meade and Thome, 2017). In such a situation, the production of biofuels from agricultural raw materials will lead to increased competition for land and other resources between food

Copyright (C) 2017 The Authors. Published by Aleksandras Stulginskis University. This is an open-access article distributed under the terms of the Creative Commons Attribution License (CC-BY 4.0), which permits unrestricted use, distribution, and reproduction in any medium, provided the original author and source are credited. 
production and energy production (Danilowska, 2014, Novak at al., 2015, Wicki, 2017). One possible solution is to reduce the consumption of first generation raw materials, i.e. those that are made from the same raw materials that are used in food production. This shall allow avoiding competition for raw materials that emerges between biofuel production and food production (Nelson, 2010).

Agricultural production must grow in order to provide food and fuel for the global population, which is becoming both more numerous and richer. Due to increasing attention paid to climate changes and biodiversity loss, the production growth must take place without taking up further areas not yet used in agriculture. One of the solutions is also the widespread use of genetically modified crops as higher yields can be obtained even under severe pest pressure (Sexton and Zilberman, 2012). Another direction is to make progress in the field of yield of the plants specially grown for energy purposes (Searle, Malins 2015).

In the world's bioenergy production only $0.8 \%$ accounts for biofuels. They are, however, produced from first generation raw materials, also used in food production. Chakravorty at al. (2009) pointed out that increasing the consumption of biofuels would result in higher raw material prices and subsequently occupation of further arable areas for the production, including the areas currently afforested. Similar conclusions are presented in many studies (Gilbert and Muger, 2017, Kupczyk et al., 2017, Zoladkiewicz, 2016). Other results were obtained by Zhang at al. (2010) and Ondrej at al. (2017) who showed in their studies that there is no significant correlation between maize prices (used in bioethanol production) and oil prices. Bentivoglio, and Rasetti (2015), although they did not confirm the existence of a link between the prices of biofuels and food prices, they do not exclude the existence of such dependence. Obadi and Korcek (2014) pointed out that this change in prices for agricultural products was due to changes in oil prices due to the impact on production costs. The assessment of the strength and direction of dependence is also impeded by the fact that, for example, the US requires both minimum biofuel consumption and production limits (Gilbert and Muger, 2017). So far, it can be said first and foremost that the development of biofuel production involves the occupation of larger areas of agricultural land for their production, and that this can lead to a reduction in the potential of food production. The links between the use of agricultural raw materials for the production of biofuels, the prices of fossil fuels and food prices are still not fully explained.

In 2015 , the production of liquid biofuels accounted for around $2.8 \%$ of world demand for transport fuels. The installed power of biomass power plants was $88 \mathrm{GW}$ and the average annual growth rate in 2004-2013 was $12 \%$. Total energy production from biomass for heat, electricity and transport was estimated at $60 \mathrm{EJ}$, with an average annual increase of $20 \%$ (REN21, 2016). The share of bioenergy has been relatively constant since 2010 , and amounted to $10 \%$ in spite of the $24 \%$ increase in production.

The global production of biofuels was 133 billion litres in 2015. In 2004 it was only 33 billion litres. The main fuel was ethanol with a $74 \%$ share in production, followed by biodiesel with $22 \%$. The main producer of biofuels in the world is the USA. In 2015, bioethanol production in the US was 56 billion litres and 30 billion litres in Brazil. The largest producers in the production of biodiesel are USA, Brazil, Germany and Argentina. In 2015 it was produced 4.8 billion litres in the United States, 3.9 billion litres in Brazil and 2.8 billion litres in Germany. 11.5 billion litres of biodiesel (REN21,2016) were produced across the EU. Biodiesel production is strongly influenced by changes in fuel policy. Particularly there are new restrictions in the EU resulting from the reduction of the consumption of biofuels from first generation raw materials in transport to 7\% (Directive, 2015). The observed annual production fluctuations also result from production risk (Wicka 2013).

1.7 million People were employed in the global liquid biofuel production sector in 2015 , i.e. $21 \%$ of the total of 8 million working in the renewable energy sector (REN21, 2016). Biofuel production also leads to the modernization of the agribusiness structure (Wicki and Wicka 2016).

\section{AIM AND METHODOLOGY}

The aim of the study is to assess the dynamics of the growth of liquid biofuel production in the world and the prospects for growth.

The following research tasks were carried out: 1) the volume and dynamics of liquid biofuel production in the world have been determined; 2) the development prospects of the production have been determined, 3) the quantity and share of biofuel production in the consumption of the main agricultural raw materials have been presented.

The analysis covered the period 2005-2016 and the forecast was made up to 2025.

The data used in the study came from FAO and OECD statistical databases and REN21 reports. Simple methods of analysis were used in the development of the results, the dynamics and structure indicators were employed to describe the time series. An exponential function was used in the assessment of growth dynamics in accordance with the formula in MS Excel: ,, $=\ln \left(\right.$ indeks $\left.\left(\operatorname{regexpp}\left(\mathrm{X}_{0}: \mathrm{X}_{\mathrm{n}}\right) ; 1 ; 1\right)\right)$ ”.

\section{RESULTS AND DISCUSION}

\section{Biofuels production}

Liquid biofuels are produced as bioethanol and biodiesel. Small share falls to HVO (hydrogenated vegetable oil), which is produced from some vegetable oils. In the years 2005-2016, total biofuel production in the world increased from 37 to 130 billion litres (fig. 1). Bioethanol production increased from 33 to 99 billion litres and biodiesel production from 4 to 31 billion litres. This represented an increase by $790 \%$ for biodiesel and $300 \%$ for bioethanol. Bioethanol was 
dominant in biofuel production. The share of biodiesel in 2004 was $11 \%$ and gradually increased to $23 \%$ in 2013 . Since then, this share has remained unchanged, mainly due to the slowdown in EU biodiesel production.

Changes in the volume of biofuels production were not uniform in time. Their dynamic growth was observed in 2005-2010. During this period, the Compound Annual Growth Rate (CAGR) of biodiesel production was 32\%, and for bioethanol it was $22 \%$. After 2010, the growth rate of production has been considerably weakened. In 2011-2016, it was only $7 \%$ per year for biodiesel and $4.6 \%$ per year for bioethanol production. A significant increase in production and consumption of liquid biofuels is also not predicted in the following years. The annual growth rate of $1 \%$ for biodiesel and $1.4 \%$ for bioethanol is forecasted for the years $2017-2025$.

The production of biofuels is strongly geographically concentrated. As much as $88 \%$ of the world's bioethanol production came from the US and Brazil. In biodiesel production, the EU occupies the first place, with $38 \%$ of world production. The EU, together with four other producers, i.e. the USA, Brazil, Argentina and Indonesia, produces $80 \%$ of the world's bioethanol production. Such high concentration means that political decisions on biofuels undertaken by the three main producers are decisive for the production of biofuels in the world.

The presented production volume dynamics and forecasted changes for the next 10 years indicate that the growth of biofuel production has been halted and no significant changes are anticipated. This is due to the change in the EU policy on the use of biofuels in transport, but also due to the USA policy towards biofuels. The increase in the required level of consumption of biofuels as an additive to transport fuels is not currently assumed there. In addition, it is necessary to increase the consumption of second generation biofuels in the USA.

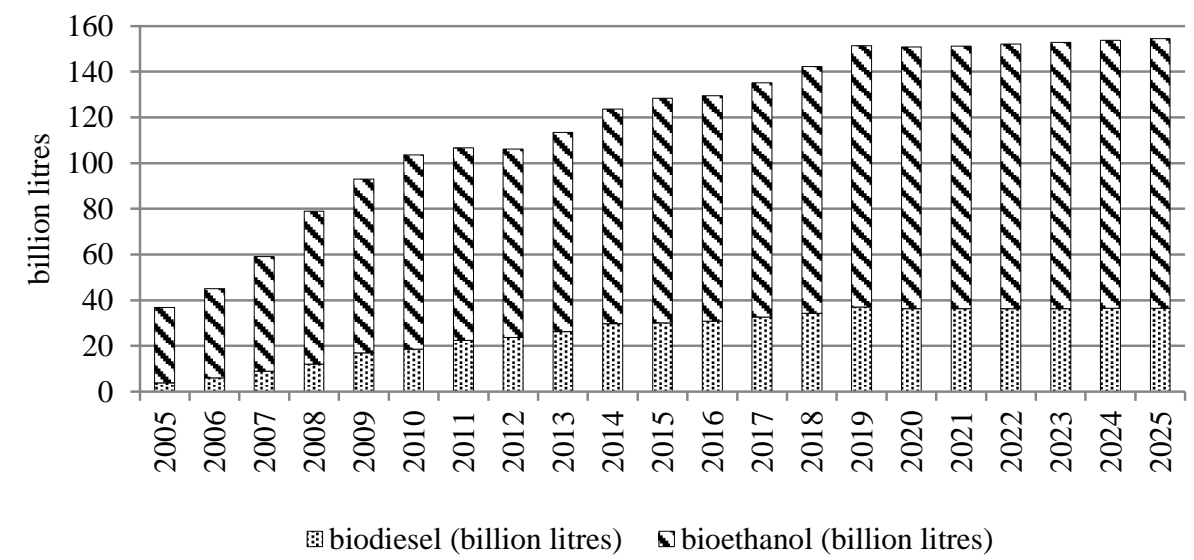

Source: own elaboration based on REN21 and OECD publications.

Figure 1. World biofuels production in years 2005-2016 with projection to 2025

\section{Raw materials used for the production of biofuels}

Various agricultural raw materials are used for the production of liquid biofuels, with a number of them dominating. For the production of bioethanol, corn is most consumed, followed by sugarcane. By-products, mainly molasses, but also other wastes containing cellulose, are also used. Biodiesel is produced from a variety of vegetable oils, mainly from soybean in South America and from rape in Europe and from food industry waste (fig. 2). It is anticipated that the use of different types of waste (second generation raw materials) will be increasingly important in the production of biodiesel, while at the same time reducing the consumption of first generation raw materials. In the years $2014-2016$, about $24 \%$ of biodiesel was produced from fat-containing waste. The share of bioethanol produced from cellulosic raw materials using advanced processing methods is still low and is only $2 \%$.

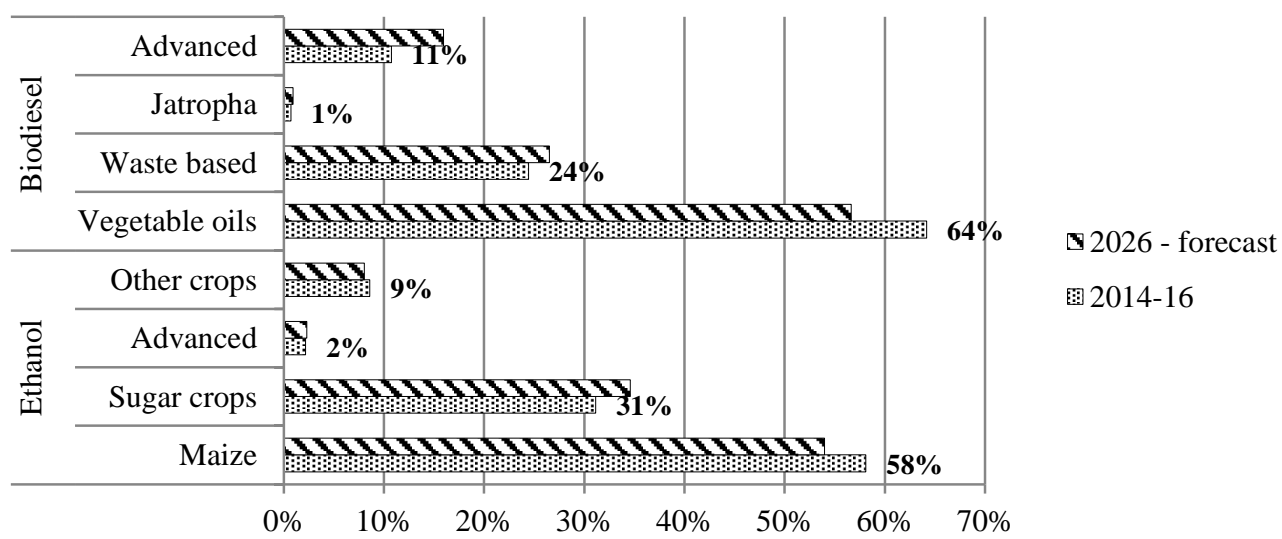

Source: OECD/FAO 2017. „OECD-FAO Agricultural Outlook”, OECD Agriculture statistics (database), http://dx.doi.org/10.1787/agr-data-enFigure 2. Share of feedstock used for biofuel production 
In some countries, for example in Argentina or Brazil, but also in the EU even up to $30-80 \%$ of the total amount of vegetable oil produced is consumed for the biofuel production. In practice, this means that agricultural production depends on the demand for biofuels but not for food. Figure 3 shows the share of vegetable oil intended for biodiesel production in selected countries. The greatest share of oil for biodiesel is allocated in Argentina where it is almost $80 \%$, while in the EU the average is around 50\%. It follows that in many countries the area of land occupied by crops used for the production of biofuels has a significant share in the total area of agricultural land. It is estimated that around 5\% of the world's arable land is used for energy production (Infiniti, 2015: 19). A further increase in the area where raw materials for biofuel production are produced may lead to reduced food production unless further increase in productivity in agriculture takes place.

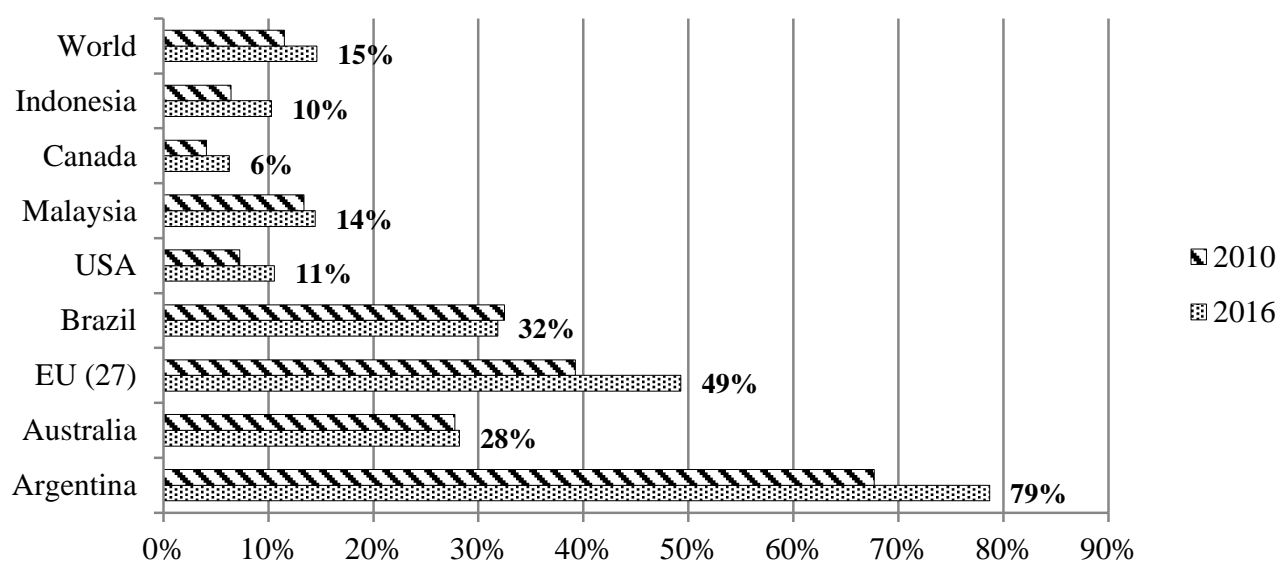

Source: own elaboration based on OECD-FAO Agricultural Outlook 2010-2019.

Figure 3. Share of vegetable oil used for biodiesel production

Significant quantities of raw materials belonging to the first generation are appropriated for the production of biofuels. In case of sugarcane it is as much as $20 \%$. Over $10 \%$ of oil plant products and maize are allocated to biofuels in the world (fig. 4). In quantitative terms, this means that 20 million tons of oil is spent annually on biodiesel production. This is equivalent of the production from approximately 17 million hectares. As much as 143 million tons of maize is also used to produce bioethanol. With a yield of 8 tons per hectare, about 20 million hectares should be allocated to production. Sugar cane and sugar beet destined for the production of bioethanol occupy about 6 million hectares. Annual production of biofuels consumes 20 million tons of vegetable oils, 6 million tons of wheat, 145 million tons of maize and other fodder crops, and about 360 million tons of sugar cane and sugar beet. These raw materials do not go to food production.

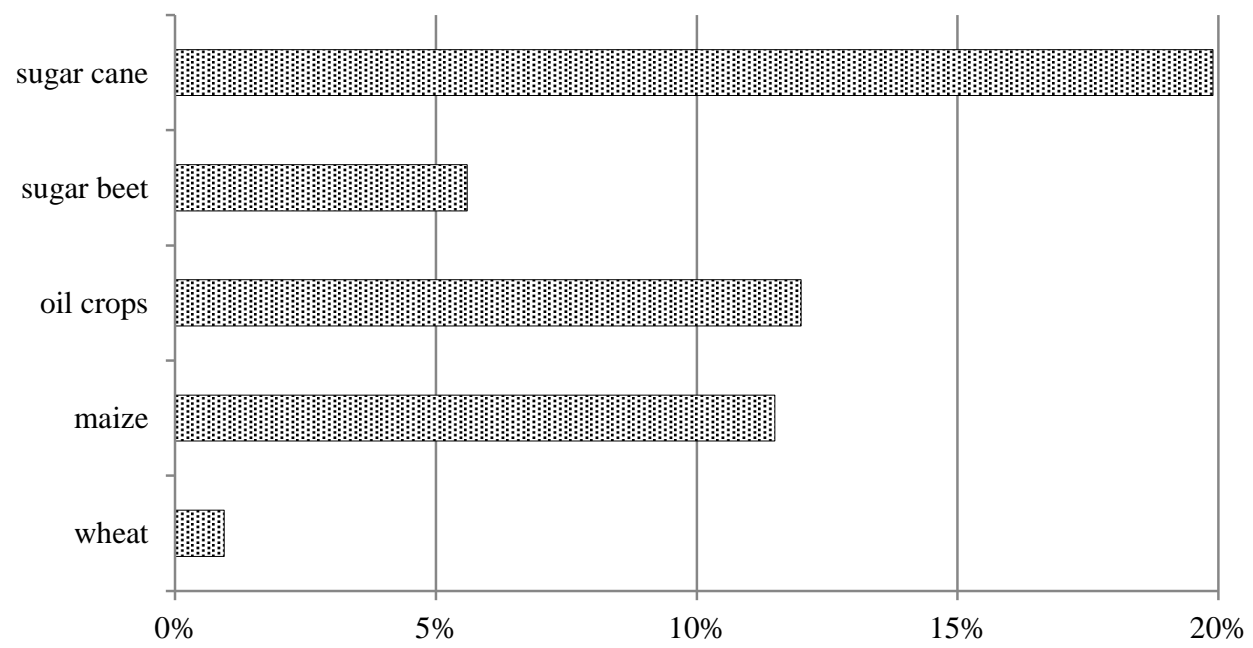

Source: own elaboration based on OECD-FAO Agricultural Outlook 2015.

Figure 4. Share of production used for biofuels production

\section{Production of liquid biofuels in Poland}

Liquid biofuels in Poland are produced from rapeseed oil and bioethanol produced mainly from cereals. In 2015, about 930 thousand tons of biodiesel and 174 thousand tons of ethanol were produced. Since 2010, biodiesel production has more than doubled, from 380,000 tons, and ethanol production by $15 \%$ from 150 thousand tons (fig. 5). The total production of liquid biofuels is about 1 billion litres. The observed annual changes are due to the interchangeability of 
rapeseed yield, which in Poland sometimes is frozen during winter. The production of raw materials for biofuels is carried out at approximately 510 thousand hectares of land, namely at about 5\% of arable land. In 2005-2007 it was only $1 \%$. More than $70 \%$ of rape produced and about $2 \%$ of cereals are used for the production of biofuels. This means that rape production in Poland is mostly allocated for biofuels and not for food production. The observed rapid growth was due to the implementation of EU policy on the production and consumption of renewable fuels in the economy, including transport. $2 \%$ of cereals production and $60 \%$ of rape production was allocated for biofuel production in Poland. Growing of rape for biofuels was subsidized within measures of Common Agricultural Policy, which resulted in a rapid increase in production. In the context of relative overproduction of raw materials in relation to food needs, the production of biofuels does not result in restrictions on food production.

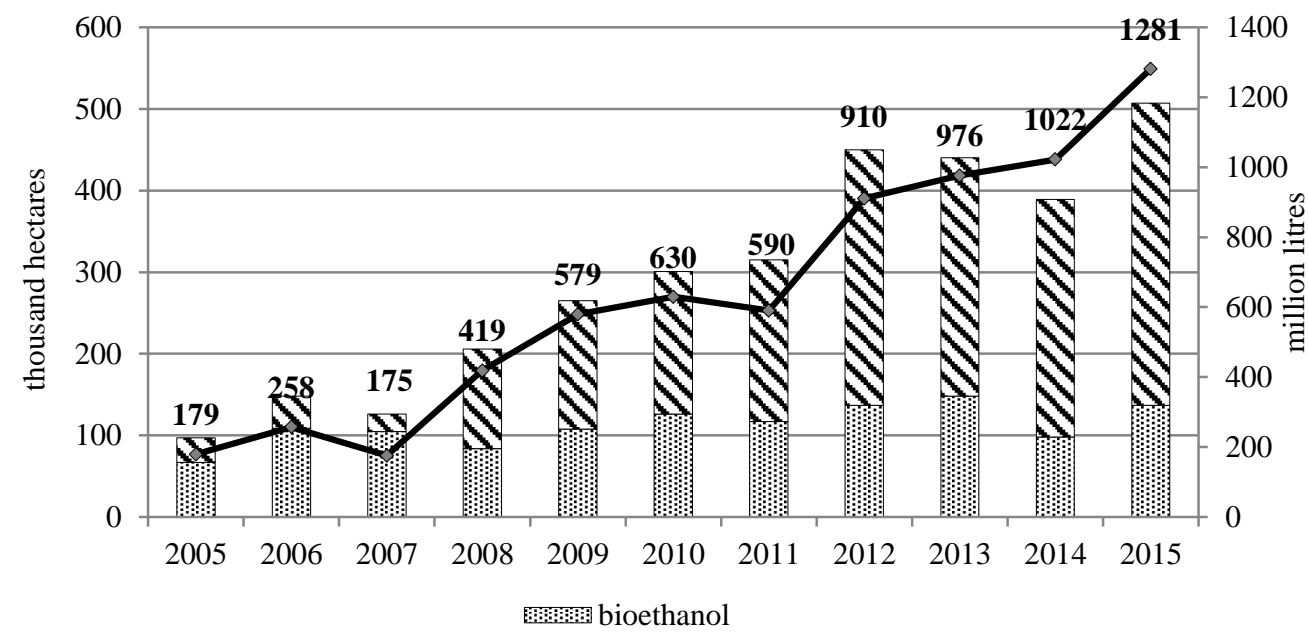

Source: own elaboration based on CSO of Poland statistical data.

Figure 5. Area dedicated for production of crops for biofuels production in Poland

\section{CONCLUSION}

Liquid biofuels are the main renewable fuel suitable for use in transport. Despite the policy of supporting their production implemented in the EU and US, their share in global fuel consumption is only $2.8 \%$. This is due to the weakening of support for the development of first generation biofuels as a result of the controversy connected with biofuel production and food production competing for land resources, but also because the first generation biofuels have shown little contribution to reducing $\mathrm{CO}_{2}$ emissions due to the need to bear high costs of fossil fuels, mineral fertilizers and plant protection products for their production. Hence, the mandatory share of biofuels in transport fuels is reduced from 10 to $7 \%$ in the EU.

World biofuel production grew rapidly in 2005-2010 to around 106 billion litres. In subsequent years, the growth rate has slowed to around 5-7\% per year and in 2016 about 130 billion litres of biofuels were produced, 74\% of which was bioethanol. In subsequent years a further growth slowdown is anticipated, to about $1 \%$ per year.

There is no empirical confirmation of the findings concerning the impact of biofuel production on food prices. Available analyses point to the co-variability of prices for fossil fuels and biofuels, with fossil fuel prices being the source of change. This situation is due to sufficient food production in the world, despite their unequal distribution and the presence of countries with food shortages.

In the structure of the raw material used for the production of biofuels the raw materials of first generation still dominate. As regards the production of biodiesel about $25 \%$ of this biofuel is produced from second generation raw materials, and it is only $2 \%$ in the production of bioethanol. Biodiesel is produced mainly from soybean oil in the Americas, from rapeseed in Europe and from palm oil in South Asia.

The growth of biofuels production in the world has slowed considerably. It should be assumed that without additional incentives outside the sector, this will not change. The amount of liquid biofuels currently being produced ensures that the minimum biofuel share in the fuels consumed in transport in the EU and US is met. Further development of production is limited also by relatively low oil prices, which makes it difficult to obtain the economic efficiency of new installations. The change of the policy of states towards first generation biofuels, whose production competes with food production, and does not produce the desired environmental effects due to its low efficiency in reducing $\mathrm{CO}_{2}$ emissions is also of great importance. The production of second generation biofuels is still of little importance.

The development of liquid biofuels production in the world slowed down after 2010 due to the gradual saturation of the EU and US market, as well as findings on the competition with food production and lower than expected positive environmental impacts. At present, biofuels production is strongly competing with other agricultural production at the areas of production. Even up to $40-70 \%$ of the total amount of rapeseed or soybean produced in the given country are allocated to biofuels. It is anticipated that the level of biofuels production from first generation raw materials will not increase but that second generation biofuels will play an increasingly important role, however, depending on the development of the processing technology and its economic effectiveness on a commercial scale. 


\section{REFERENCES}

1. Bentivoglio, D., Rasetti, M. 2015. Biofuel sustainability: review of implications for land use and food price. Rivista di Economia Agraria, LXX (1), pp. 7-31.

2. Chakravorty, U., Hubert, M., Nøstbakken, L. 2009. Fuel versus Food. Working Papers 2009-20, University of Alberta. available at: https://EconPapers.repec.org/RePEc:ris:albaec:2009_020, (Accessed on 14.10.2017)

3. Danilowska, A. 2014. Koncepcja dobr publicznych a rolnictwo (Public goods concept vs. agriculture). Research Papers of the Wroclaw University of Economics, Vol. 360, pp. 244-252.

4. Directive (EU) 2015/1513 of the European Parliament and of the Council of 9 September 2015 amending Directive 98/70/EC relating to the quality of petrol and diesel fuels and amending Directive 2009/28/EC on the promotion of the use of energy from renewable sources.

5. Fuglie, F., Rada, N. 2013. Growth in Global Agricultural Productivity: An Update, USDA, Economic Research Service available at: https://www.ers.usda.gov/amber-waves/2013/november/growth-in-global-agricultural-productivity-an-update/ (Accessed on 15.10.2017)

6. Fuglie, K., Rada, N. 2017. International Agricultural Productivity, USDA, Economic Research Service. available at https://www.ers.usda.gov/data-products/international-agricultural-productivity/ (Accessed on 21.10.2017)

7. Fuglie, K., Wang, S., Ball, V.E. 2012. Productivity Growth in Agriculture: An International Perspective. CAB International: Oxfordshire, UK. https://doi.org/10.1079/9781845939212.0000

8. Gilbert, C., Mugera, H. 2017. The effects of US biofuels policy: A structural break analysis of the WTI pass-through to the corn price. 91st Annual Conference, April 24-26, 2017, Agricultural Economics Society Royal Dublin Society, Dublin, Ireland. available at: http://ageconsearch.umn.edu/record/258646/files/Christopher_Gilbert_Link_paper_020417.pdf (Accessed on 15.10.2017)

9. Golebiewski, J., Pajak, K. 2016. A sustainable bioeconomy in Europe - the European Union's policy and strategy. Political Rents of European Farmers in the Sustainable Development Paradigm. International, national and regional perspective. PWN: Warsaw, Poland.

10. Hoogwijk, M., Faaij, A., De Vries, B., Turkenburg, W. 2009. Exploration of regional and global cost-supply curves of biomass energy from short-rotation crops at abandoned cropland and rest land under four IPCC SRES land-use scenarios. Biomass and Bioenergy, Vol. 33, pp. 26-43. https://doi.org/10.1016/j.biombioe.2008.04.005

11. Hoogwijk, M., Faaij, A., Eickhout, B., De Vries, B., Turkenburg, W. 2005. Potential of biomass energy out to 2100, for four IPCC SRES land-use scenarios. Biomass and Bioenergy, Vol. 29, pp. 225-257. https://doi.org/10.1016/j.biombioe.2005.05.002

12. IEA. 2011. Technology Roadmap: Biofuels for Transport. OECD/IEA: Paris, France.

13. IEA. 2012. Technology Roadmap: Bioenergy for Heat and Power. OECD/IEA: Paris, France.

14. Infiniti Research Limited. 2015. Global Agroscience Market 2015-2019. Technavio.com.

15. Kupczyk, A., Maczynska, J., Sikora, M., Tucki, K., Zelazinski, T. 2017. Stan i perspektywy oraz uwarunkowania prawne funkcjonowania sektorow biopaliw transportowych w Polsce (Situation, prospects and legal conditions associated with functioning of the transport biofuels sectors in Poland). Roczniki Ekonomii Rolnictwa i Rozwoju Obszarow Wiejskich, Vol. 104(1), pp. 39-55. https://doi.org/10.22630/RNR.2017.104.1.3

16. Meade, B., Thome, K. 2017. International Food Security Assessment. 2017-2027, GFA-28, USDA, Economic Research Service.

17. Nelson, G. 2010. Are Biofuels the Best Use of Sunliht? [in] M. Khanna, J. Schefran, D. Zilberman (eds.) Handbook of Bioenergy Economics and Policy. Springer: New York. https://doi.org/10.1007/978-1-4419-0369-3

18. Novak, P., Masek, J., Hula, J., Benes L., Kumhalova, J. 2015. Soil tillage focusing on the reduction of water erosion of soil in the cultivation of selected field crops. Proceedings of the 7th International Scientific Conference Rural Development 2015, pp. 1-5. https://doi.org/10.15544/RD.2015.015

19. Obadi, S., Korcek, M. 2014. Are Food Prices Affected by Crude Oil Price: Causality Investigation. Review of the Integrative Business and Economics Recourses, Vol. 3(1), pp. 411-427.

20. Ondrej, F., Janda, K., Kristoufek, L., Zilbermam, D. 2017. Food versus fuel: An updated and expanded evidence, Energy Economics. https://doi.org/10.1016/j.eneco.2017.10.033

21. REN21. 2014. 10 Years of Renewable Energy Progress. REN21 Secretariat: Paris, France

22. Sands, R., Malcolm, Suttles, S., Marshall, E. 2017. Dedicated Energy Crops and Competition for Agricultural Land. ERR-223, U.S. Department of Agriculture, Economic Research Service, January 2017.

23. Searle, S., Malins, C. 2014. Will energy crop yields meet expectations? Biomass and Bioenergy, Vol. 65, pp. 3-12. https://doi.org/10.1016/j.biombioe.2014.01.001

24. Searle, S., Malins, C. 2015. A reassessment of global bioenergy potential in 2050. GCB Bioenergy, Vol. 7, pp. 328-336. https://doi.org/10.1111/gcbb.12141

25. Sexton, S., Zilberman, D. 2012. Land for Food and Fuel Production: The Role of Agricultural Biotechnology. [in] J. Graff Zivin, J. Perloff (eds.) The Intended and Unintended Effects of U.S. Agricultural and Biotechnology Policies. NBER: Chicago, U.S., pp. 269-288. https://doi.org/10.7208/chicago/9780226988061.003.0009

26. Wicka, A. 2013. Czynniki i mozliwosci ograniczania ryzyka w produkcji roslinnej poprzez ubezpieczenia (Factors and opportunities for risk mitigation in plant production using insurance). Wydawnictwo SGGW: Warszawa, Poland. [In Polish]

27. Wicki, L. 2017. Food and Bioenergy - Evidence from Poland. Economic Science for Rural Development, Vol. 44, pp. $299-305$.

28. Wicki, L., Wicka, A. 2016. Bio-Economy Sector in Poland and Its Importance in the Economy. Economic Science for Rural Development, Vol. 41, pp. 219-228. 
29. Zhang, Z., Lohr, L., Escalante, C., Wetzstein, M. 2010. Food versus fuel: What do prices tell us? Energy Policy, Vol. 38, pp. 445-451. https://doi.org/10.1016/j.enpol.2009.09.034

30. Zoładkiewicz, A. 2017. Ekonomiczno-ekologiczne aspekty produkcji biopaliw cieklych (Economic and ecological aspects of the production of liquid biofuels), Annals of The Polish Association of Agricultural and Agribusiness Economists 18(3), pp. 427431. 